\title{
$\mathrm{UHPC}$ 를 적용한 PS 정착부의 응력해석
}

김지상* $\cdot$ 최윤석**

Kim, Jee Sang*, Choi, Yoon Seok**

\section{Stress Analysis of PS Anchorage Zone Using Ultra High Performance Concrete}

\begin{abstract}
The post-tensioned anchorage zones of normal concrete have larger cross sections because of congested reinforcements to resist high bearing and bursting stresses. The high compressive and tensile strength of newly developed UHPC (Ultra High Performance Concrete) may reduce the cross sectional dimensions and simplify the reinforcement details, if used for post-tensioned members. The Finite Element Analysis was performed to evaluate the mechanical behavior of post-tensioned anchorage zones using UHPC without anchorage plates and confining reinforcements. The results show that the maximum bursting stresses are less than the values given in current design code without failure due to vertical cracks. The location of maximum bursting stresses were at 0.2 times of width of the models. The bursting force from FEA is less than that is obtained using simplified formular in Korean Bridge Design Code.
\end{abstract}

Key words : UHPC, Anchorage zone, Stress analysis, Bearing stress, Bursting force

\section{초 록}

현재 사용되는 보통 콘크리트를 이용한 PS 정착부는 응력 집중에 의한 복잡한 배근상세로 단면이 커지고, 인장응력에 저항하기 위한 추가적인 철근이 많이 배근되어 시공성이 저하된다. 그러나, 최근 개발된 UHPC를 PS 부재에 적용할 경우 높은 강도와 우수한 역학적 특성으로 인해 단 면 축소 및 PS 정착부의 복잡한 배근상세를 단순화 할 수 있을 것으로 기대된다. 따라서, 이 논문에서는 UHPC 재료의 역학적 특성을 적용하여 보통 콘크리트에 비해 단면을 축소하고 별도의 정착장치와 구속철근이 없는 PS 정착부의 역학적 거동을 유한요소해석 방법을 이용하여 수행하 였다. 그 결과, 최대 파열응력은 수직균열에 의한 파괴없이 저항할 수 있는 하중재하능력 기준을 만족하였으며, 발생위치는 단면 폭의 0.2 배 되 는 위치에서 발생하였다. 또, 도로교설계기준에서 제시된 근사해법의 파열력과 유한요소해석 결과를 비교한 결과 구속철근 보강 없이도 파열력 에 저항할 수 있는 하중재하능력 기준을 만족하는 결과를 확인 할 수 있었다.

검색어 : UHPC, PS 정착부, 응력해석, 지압응력, 파열력

\section{1. 서론}

가장 널리 사용되고 있는 건설재료 중 하나인 콘크리트는 구조물의 대형화, 다양화 및 고층화가 강조되면서 다양한 역학적 성질이 요구되고 있어 이에 대한 대응의 하나로 초고성능 콘크리트(UHPC, Ultra High Performance Concrete)의 개발 및 적용이 활발히 이루어지고 있다(Boulay et al., 2004; Behlul et al., 2004; Hajar et al., 2004). 프랑스, 독일, 미국 및 일본 등의 선진국의 경우 체계적인 연구 수행을 통해 많은 성과를 얻었고, 이를 중소지간 도로교, 보도교 및 철도교 등에 실제 적용하기 위한 노력을 시작하는

* 정회원·교신저자·서경대학교 토목건축공학과 교수 (Corresponding Author·Seokyeong University·zskim@skuniv.ac.kr)

** (주)티엠이앤씨 사원 (cyschoi87@naver.com)

Received July 4 2012, Revised December 29 2012, Accepted June 272013 
단계에 이르렀다(AFGC/SETRA, 2002; JSCE, 2004; DAfStb, 2008; FHWA, 2006).

우리나라에서는 개발된 $\mathrm{UHPC}$ 를 활용하여 장지간 사장교의 설계 및 시공을 위한 연구가 진행 중인데, 그 적용성을 확보하는데 장지간 교량의 상부구조로 효과적인 포스트텐션 거더의 설계 기술 을 확보하는 것이 긴요하다(한국건설기술연구원, 2011). 보통 콘크 리트를 적용한 정착부의 경우 정착장치간의 거리유지, 자유단과의 이격거리 확보 및 높은 지압응력 발생 등의 원인으로 거더의 일반부 에 비해 단면이 확대되는 문제가 발생하게 된다. 그러나, $\mathrm{UHPC}$ 를 적용하는 경우 강섬유 보강으로 인해 부재단면의 축소 및 균열 발생 억제의 효과에 더하여, 프리스트레스 힘에 의한 응력 집중에 저항하기 위하여 배근된 복잡한 철근 상세를 갖는 정착구역의 설계를 단순화하여 효율적이고 경제적인 설계가 가능할 것으로 기대된다(Toutlemonde F. et al., 2007). 따라서, 교량구조물의 건설에 널리 쓰이는 부재에 국내에서 개발된 UHPC의 높은 인장 저항능력을 반영하고 이를 통한 정착구역 철근의 조밀화 및 부재단 면 확대를 방지하는 것을 목적으로 연구를 수행하였다. 이 논문에서 는 무보강 해석 모델 및 보통 콘크리트에 적용되는 배근상세를 적용한 해석 모델을 대상으로 유한요소법을 이용하여 정착부의 응력해석을 수행하여 각 모델의 응력분포 및 응력의 크기를 비교하 였다. 즉, UHPC 부재의 프리스트레스트 콘크리트 부재에 대한 적용성을 확인하여 합리적인 정착구역 설계를 할 수 있도록 정착부 의 균열 발생 및 파괴에 영향을 주는 인장력의 발생위치 및 크기,
정착판의 크기와 부재단면치수의 상대적인 관계 등을 유한요소해 석을 통하여 파악하는 응력해석을 수행하였다. 이 연구를 통하여 $\mathrm{UHPC}$ 를 이용한 정착부의 거동에 대한 기본개념을 정립할 수 있을 것으로 기대된다.

\section{PS 정착부의 응력분포 및 연구동향}

\section{1 정착구역의 응력 분포}

정착구역은 프리스트레스트 콘크리트 부재에서 긴장재를 정 착하여 정착장치에 집중된 프리스트레스 힘을 횡방향으로 분산 시켜 단면 전체에 선형의 응력 분포가 되도록 하는 콘크리트 부분을 말한다(국토해양부, 2010). 설계상의 목적으로 정착구역 은 일반구역(general zone)과 국소구역(local zone)으로 구분하 며, 긴장력이 구조물에 분산되어 인장응력이 작용하는 지역이 일반구역이고, 정착구 바로 앞의 높은 압축응력이 작용하는 지역이 국소구역으로 Figure 1은 일반구역과 국소구역의 정의를 나타낸 것이다.

\subsection{1 파열응력}

정착부에 프리스트레스 힘이 도입되면 하중재하면 바로 아래에 서는 높은 압축응력이 발생하며, 하중재하면에서 어느 정도 떨어진 위치(응력계도가 볼록한 영역)에서 Figure 2와 같이 최대인장응력 이 발생하고, 그 이후부터는 인장응력이 감소하여 단면 폭만큼

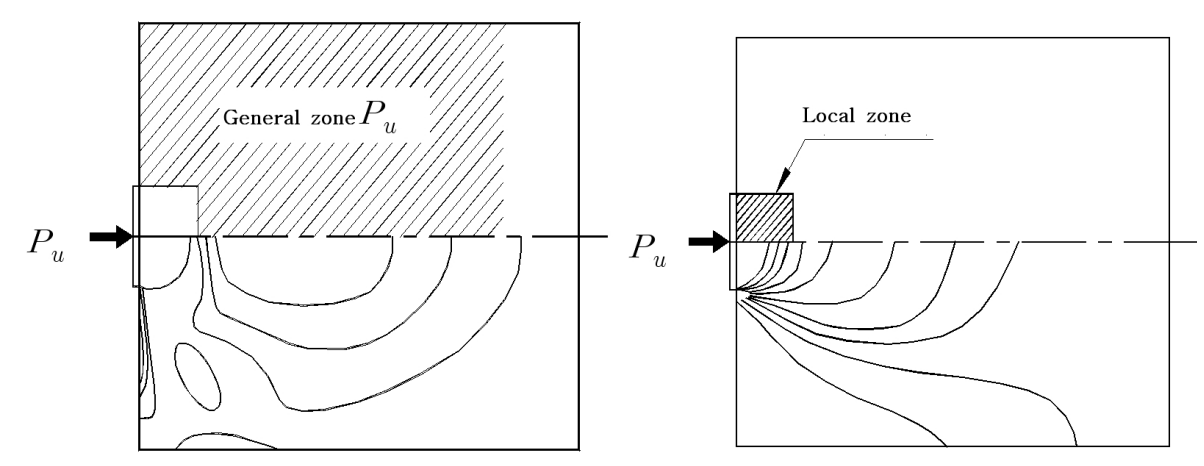

Fig. 1. General zone and local zone (Korea Ministry of Land, Transport and Marine Affairs, 2010)
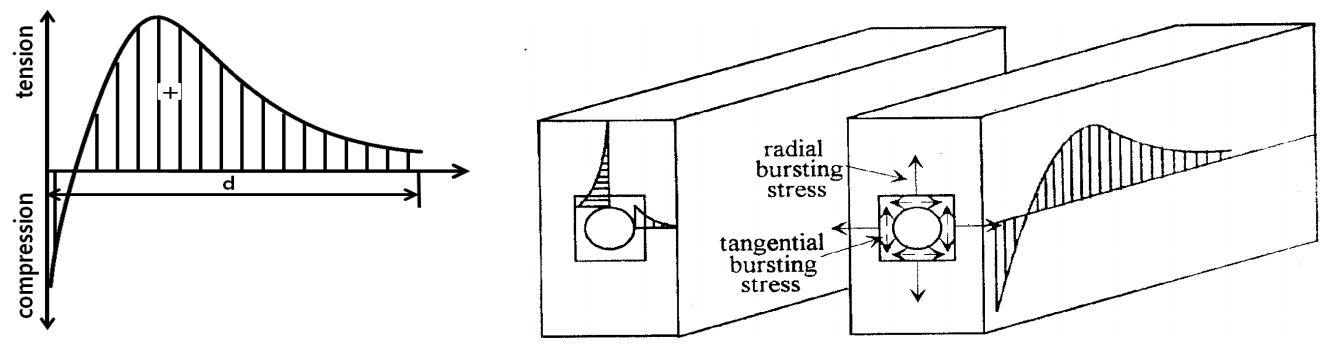

Fig. 2. Distribution of bursting stresses (Oh et al., 1994)

1350 Journal of the Korean Society of Civil Engineers 
떨어진 위치에서는 응력이 ' 0 '으로 수렴하게 되는데, 이 인장응력을 파열응력이라 한다.

\subsection{2 지압응력 및 단부인장력}

콘크리트 부재에서는 프리스트레스 힘이 정착구를 통해 모두 전달되기 때문에 정착구 바로 아래(응력궤도가 오목한 영역)에 매우 큰 압축응력이 집중적으로 발생하며, 이를 지압응력이라 한다. 하중재하면 양 끝단 국소 영역에서 재하면에 평행하게 인장응력이 발생하며, 이를 단부인장력이라고 한다. 일반적으로 PS 정착부의 균열발생 또는 파괴는 주로 지압응력이나 파열응력에 의하여 일어 나는 것으로 알려져 있으며, 상대적으로 단부인장력의 영향은 크지 않다.

\section{2 보통 콘크리트를 이용한 정착부 연구}

오병환 등(1994)은 복수 정착구가 설치된 박스 거더의 정착단부 파열거동 구명을 위해 단일 텐던과 복수 텐던이 설치된 실물 크기의 박스 거더 실험체를 제작하여 인장실험을 수행하였고, 그 결과 파열균열은 정착판의 폭 만큼 떨어진 위치에서 최초로 발생하고, 파열 변형률은 복수 텐던 실험체보다는 단일 텐던 실험체에서 크게 발생함을 확인하였다. 포항산업과학연구원(2010)은 콘크리 트 표준 시방서에 규정된 시험법인 KCI-PS101(한국콘크리트학회, 2009)에 따라 설계강도 $35 \mathrm{MPa}$ 의 일반콘크리트를 사용하여, 기존 에 상용화되어 있는 정착구 시스템에 대한 고강도 강연선의 적용성 을 평가하는 실험을 수행하였으며, 그 결과 최대하중은 허용치의 $1.01 \sim 1.12$ 배의 수준인 것으로 확인하였고, 특히, $19 \mathrm{Hole}$ 이상 정착구를 사용하는 대형 실험체의 경우에는 이 보다 작은 크기의 정착구를 적용한 실험체에 비해 상대적으로 높은 수준의 여유도를 가지고 있는 것으로 확인되었다. 최규천 등(2010)은 표준 PSC I 거더의 정착단부 파열보강철근 배근상세를 개선하기 위한 기초 연구로서 평균 압축강도가 $53 \mathrm{MPa}$ 이고, 강연선 19 가닥을 사용하는 $30 \mathrm{~m}$ 표준 PSC I 거더와 동일한 단부형상을 갖는 부재에 파열보강 철근을 배근하여 정착단부에서의 파열거동을 연구하는 실험을 수 행하였다. 이에 따르면, 수평방향 파열보강철근을 별도의 해석없이 수직방향 파열보강철근과 동일한 간격으로 배근해서는 안 되고, 수평방향 파열보강철근에 대해서도 도로교설계기준 등에 제시된 해석방법을 이용하여 보강량 및 배근 간격을 산정하여 설계해야 함을 확인하였으며, 일반적인 설계 긴장력 수준에서는 정착단부에 파열균열이 발생하지 않는 것을 확인하였다. Boulay et al. (2004) 은 콘크리트의 압축강도에 대한 프랑스 설계기준의 타당성 여부를 확인하기 위한 연구로서 단면 $200 \times 200 \mathrm{~mm}$, 높이 $600 \mathrm{~mm}$ 의 각기둥 모양의 실험체를 제작하고, 압축강도 $50 \mathrm{MPa}, 70 \mathrm{MPa}, 105 \mathrm{MPa}$ 및 $110 \mathrm{MPa}$ 의 보통 콘크리트 및 섬유보강 콘크리트를 재료로 하여
실험을 수행하였다. 그 결과, $80 \mathrm{MPa}$ 이상의 강도를 갖는 콘크리트의 경우 일시적인 불안정한 상태를 이끌며 표면의 갑작스런 파괴가 발생하는 점을 고려해야하고, 변위계로 확인된 초기 균열 응력과 기준에 제시된 허용 설계 응력을 비교하면 압축강도가 증가함에 따라 안전율이 감소하는 것을 확인하였다.

\subsection{UHPC를 이용한 PS 정착부 연구}

프랑스 LCPC의 Toutlemonde F. 등은 정착부에 구속철근을 두지 않고 $\mathrm{UHPC}$ 와 정착장치만을 적용하여 제작한 정착구의 파괴 거동에 관한 연구를 수행하였다(Toutlemonde F. et al., 2007). 실험은 EOTA(European Organization for Technical Approvals) 의 ETAG-013(European Technical Agreement Guide No.13)에 서 규정한 실험방법(EOTA, 2002)을 따랐으며, 하중재하 시 블록 상부면으로부터 $0.7 b$ 및 $1.5 b$ ( $b=$ 단면폭)의 위치에서 횡방향 변형률을 계측하였고, 블록 중심축을 따라서 블록 상부면으로 $0.5 b$ $\sim 1.7 b$ 사이의 거리에 대해서 수직변형률을 계측하였으며, 블록중 심축을 따라 전체 수직변위를 계측하여, 블록 시편의 4 면에 대해서 총 16 개의 계측점을 두었다. 그 결과, 혼입된 섬유의 구속 영향으로 정착부에 구속철근을 배근하지 않아도 설계하중 $F_{p r g}$ 에 대해 안전율 $1.3 \sim 2.1$ 이 확보가 가능한 것으로 나타났으며, $0.8 F_{p r g} \sim 1.2 F_{p r g}$ 의 범위에서 균열이 발생하고 비선형 거동이 시작되는 것으로 나타났 다. 또 균열은 상부 재하면에서 블록 폭의 2 배 위차까지 진전되므로 $\mathrm{UHPC}$ 정착부 실험을 위한 시편 제작 시에는 블록의 높이를 폭의 3 배 이상으로 해야 할 것을 제안하고 있다.

\section{3. 정착부 거동 해석}

\section{1 해석 모델}

이 연구에서는 $\mathrm{UHPC}$ 의 높은 강도특성을 고려하여, 정착장치와 구속철근이 없는 정착부를 모델링하여 정착구역의 파열응력 및 횡방향 변형률 분포를 구하였다. 해석 모델은 기존의 보통 콘크리트 와 다른 $\mathrm{UHPC}$ 의 높은 압축강도 및 인장강도로 인해 단면 치수를 축소할 수 있는 장점을 고려할 수 있게 기존의 상용 정착장치 중 소형의 정착장치를 사용하는 것이 적합하다는 판단(한국건설기 술연구원, 2011)에 따라 정착판의 크기는 $215 \times 215 \mathrm{~mm}$, 정착장치 의 길이가 $160 \mathrm{~mm}$ 인 VSL사의 인장정착구 VSL Type EC의 6-7 모델(정착장치와 재하판 일체형)을 사용하였다. 이 장치의 제원을 바탕으로 해석 모델의 단면 크기를 결정하기 위해 단면과 정착판의 크기 및 단면 폭 크기에 따른 최대 파열응력 분포를 확인하는 해석을 수행하였다. Figure 3 은 단면의 크기를 결정하기 위한 해석 결과를 정리한 내용으로, 정착판의 크기를 $215 \mathrm{~mm}$ 로 일정하게 하고 단면 폭을 $200 \mathrm{~mm} ~ 300 \mathrm{~mm}$ 까지 증가시켜 파열응력의 크기 


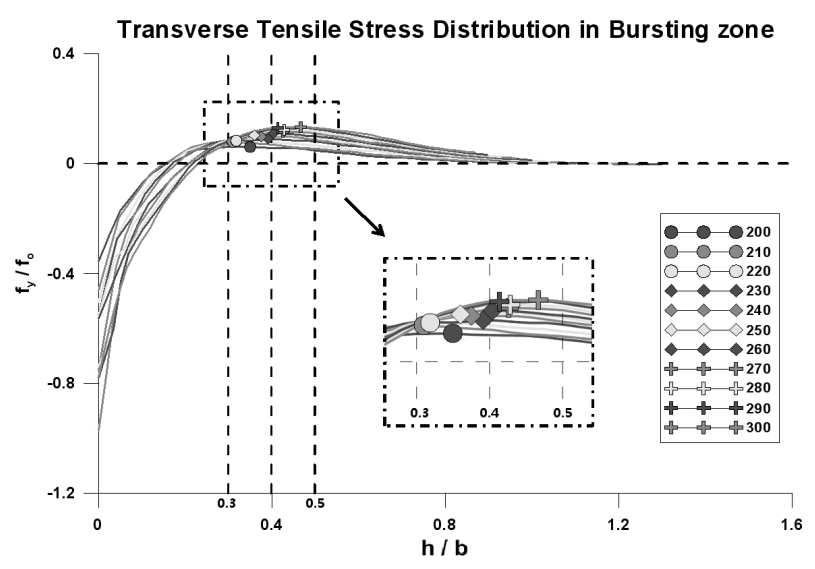

Fig. 3. Preliminary stress analysis to determine model dimensions

와 위치를 확인하였다. 응력의 크기는 해석모델에 발생하는 평균압 축응력으로 정규화하여 나타내었다. 이 때, $\mathrm{X}$ 축은 단면 폭에 대한 길이방향(h)의 비율이며, $\mathrm{Y}$ 축의 $f_{u}$ 는 유한요소 해석결과에 대한 파열응력을 나타내고, $f_{o}$ 는 응력집중을 고려하지 않은 평균 등분포 응력이다. 해석결과 정착판의 크기를 일정하게 하고 단면 폭의 변화를 주어도 최대 파열응력의 위치는 길이방향으로 상부면(하중 재하면)에서 $0.3 b \sim 0.5 b$ 떨어진 위치에서 발생하는 것을 확인하였 다. 따라서, 위의 결과를 바탕으로 단면의 크기는 정착판의 크기 $(215 \mathrm{~mm})$ 에서 모든 방향으로 $50 \mathrm{~mm}$ 씩 여유를 갖는 단면 치수인 $315 \mathrm{~mm}$ 로 결정하였다.

또, 해석 모델에 작용하는 하중은 도로교설계기준(2010)에 따라 $\mathrm{PS}$ 강선의 허용응력을 기준으로 결정하였으며, 강선은 SWPC 7B 를 이용하여 인장하중 $260 \mathrm{kN}$ 을 기준으로 적용하였다. 이 때, 설계 하중은 7 개의 강연선을 사용하는 정착장치의 경우 $1,820 \mathrm{kN}$ 이 된다. 따라서, 유럽기준인 ETAG-013에서 제시한 수직균열에 의한 파괴없이 저항할 수 있는 하중재하능력의 기준인 $F_{u} \geq 1.1 F_{p k}$ $=2,002 \mathrm{kN}$ 를 적용하여 해석을 수행하였다.

$\mathrm{UHPC}$ 정착부의 경우 파괴 시 균열이 단면 폭의 2 배까지 진전된 다는 결과(Toutlemonde et al. 2007)를 바탕으로 부재의 높이는 단면 폭의 4 배 $(1,260 \mathrm{~mm})$ 로 결정하였다. 앵커헤드와 정착판의 크 기는 VSL사의 정착장치 크기를 기준으로 앵커헤드의 지름은 $150 \mathrm{~mm}$, 높이는 $60 \mathrm{~mm}$ 로 결정하였으며, 정착판의 크기는 가로, 세로 각각 $215 \mathrm{~mm}$, 높이는 $215 \mathrm{~mm}$ 로 결정하였다. 해석은 범용유한 요소해석 프로그램인 Midas FEA(Midas IT, 2006)를 이용하였으 며, 4절점 솔리드 요소를 이용하여 유한요소해석을 수행하였다. 해석 모델에 사용한 재료의 특성은 UHPC의 경우 압축강도 $180 \mathrm{MPa}$, 인장강도 $13 \mathrm{MPa}$ 및 탄성계수 $45 \mathrm{GPa}$ 을 사용하였고, 앵커헤드와 정착판의 경우는 SM400의 재료를 사용하여 해석을 수행하였다.(한국건설기술연구원, 2010; 김지상, 2011)

\section{2 해석 결과 분석}

전술한 해석 모델을 이용하여 모델의 정착판 및 구속철근 보강 여부를 변수로 하여 횡방향에 따른 표면 및 내부(횡단면)의 응력 - 변형률 분포를 구하였는데, 해석 위치는 Figure 4에서 보인 바와 같이 총 네면 중 단면의 대칭을 고려하여 전면에서 표면 및 내부의 응력 및 네 면을 계산하였다. 표면의 계산 위치는 전면의 하중 재하면부터 $10 \mathrm{~mm}, 0.3 b(b=315 \mathrm{~mm}), 0.5 b, 1.0 b$ 떨어진 위치와 단부(좌측모서리)에서 $10 \mathrm{~mm}, 60 \mathrm{~mm}, 110 \mathrm{~mm}, 157.5 \mathrm{~mm}(0.5 b)$ 떨어진 위치로 하였으며, 내부의 분포 또한, 표면과 같은 위치에서 응력을 계산하였는데, 내부의 빈 공간으로 인해 UHPC의 끝부분까 지만 분포를 확인하였다. 정착판 및 구속철근이 없는 무보강 해석모 델의 명칭은 NTP-NSR로 정의하였는데, 이는 7개의 강연선(Strand) 을 사용하는 정착장치를 적용한 것으로 NTP는 No-Trumpet으로 정착구(Trumpet)가 없다는 뜻이며, NSR은 No-Spirals로 나선보 강철근(Spirals)이 없다는 뜻이다. 즉, NTP-NSR은 7개의 강연선 을 사용하는 정착장치를 적용하여 정착구 및 나선철근 보강을 하지 않은 무보강 해석 모델을 뜻하는 것이며, 정착판 및 구속철근이 있는 해석 모델은 TP-SR로 칭한다.

\subsection{1 무보강 모델(NTP-NSR)의 응력분포}

(1) 표면의 응력분포

별도의 보강장치를 고려하지 않은 무보강 해석 모델에 대한 응력해석 결과에 따라 표면의 횡방향 응력 $F_{p r g}$ 분포를 나타낸 것이 Figure 5인데, 이 중 (a) 및 (b)는 하중재하면(상부면)으로부터 $10 \mathrm{~mm}, 0.3 b, 0.5 b$ 및 $1.0 b$ 떨어진 위치에서의 계산한 값이다.

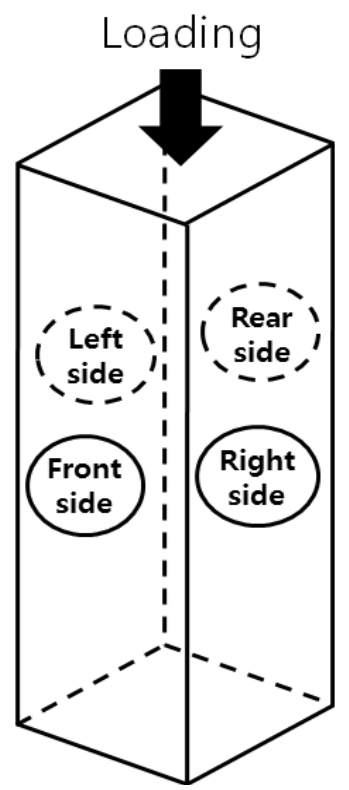

Fig. 4. Locations of stress evaluation 


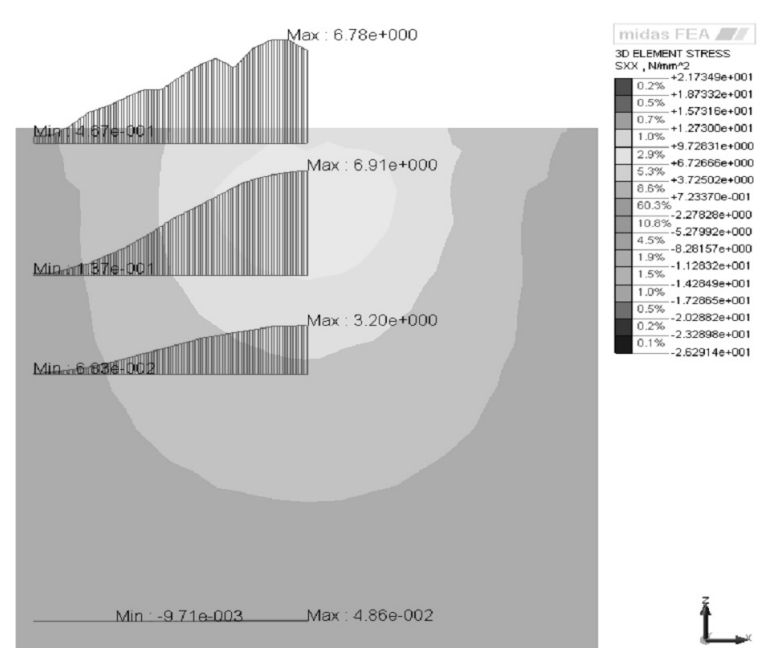

(a) Lateral stress distributions(surface)

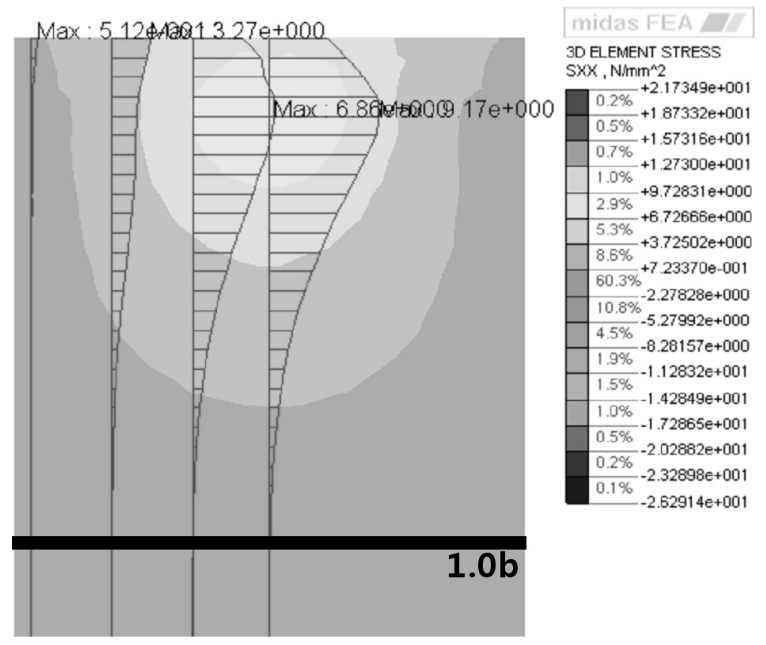

(c) Longitudinal stress distributions(surface)

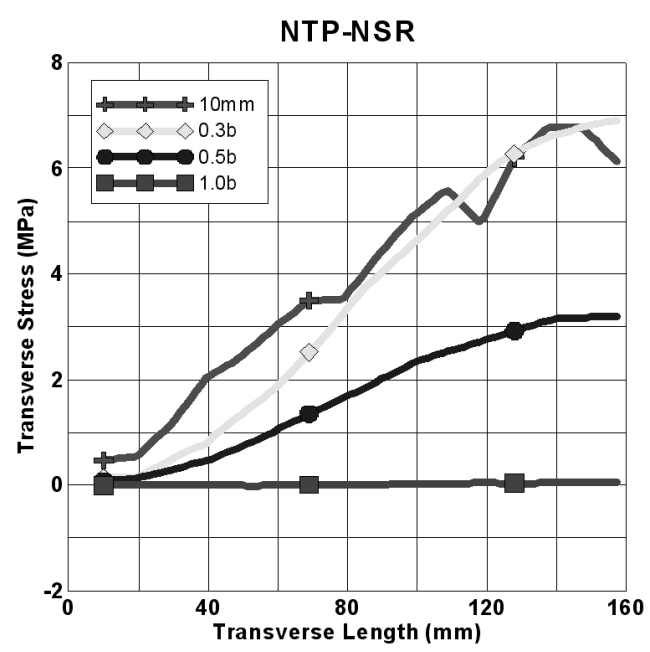

(b) Lateral stress changes(surface)

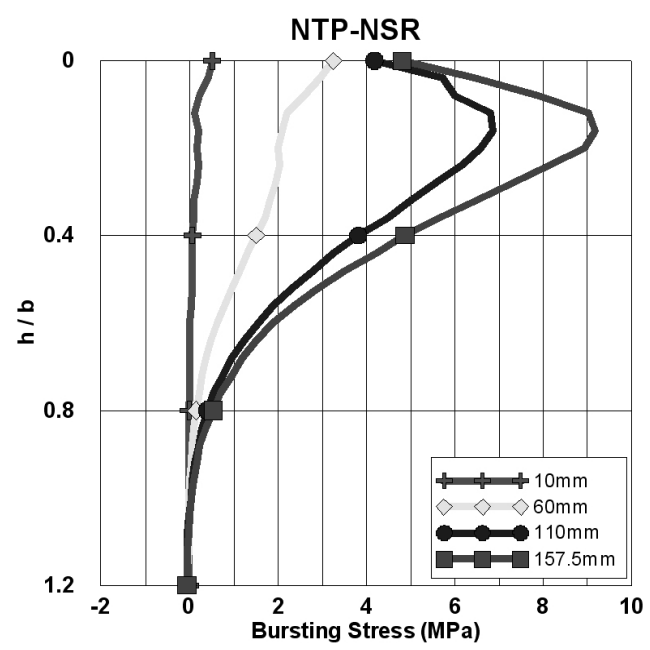

(d) Longitudinal stress changes(surface)

Fig. 5. Stress distributions on surface(un-reinforced model)

상부면에서 $10 \mathrm{~mm}$ 떨어진 위치에서는 해석 모델 중앙 $(157.5 \mathrm{~mm})$ 으로 가면서 응력이 불규칙한 분포를 보이며 크기가 증가하고 최대 인장응력은 해석 모델 중앙에서 $6.78 \mathrm{MPa}$ 의 값을 보였다. $0.3 b$ 와 $0.5 b$ 위치의 응력은 해석 모델의 좌측 단부에서 $0 \mathrm{MPa}$ 에 가까운 응력 값을 보였으며, $10 \mathrm{~mm}$ 떨어진 위치에 비해 선형적인 분포를 나타냈고 응력의 크기는 동일하게 해석 모델 중앙으로 갈수록 응력이 증가하고 최대 인장응력 또한 해석 모델 중앙에서 각각 $6.91 \mathrm{MPa}$ 과 $3.20 \mathrm{MPa}$ 의 값을 나타냈다. 또, $1.0 \mathrm{~b}$ 떨어진 위치에서는 $0 \mathrm{MPa}$ 정도의 일정한 값을 나타내는데, 이는 생베낭트 (St. Venant)의 이론과 같은 분포를 나타냈다. 따라서, 횡방향 응력은 해석 모델 중앙으로 갈수록 큰 응력을 나타냈으며 해석 모델 중앙에서 가장 큰 응력 값을 나타냈다. 또, 계측된 위치 중 상부면에서 $0.3 b$ 떨어진 위치에서 가장 큰 응력이 나타났다. Table
1은 무보강 해석 모델 표면에서 발생한 횡방향 응력분포의 최대 인장응력과 발생한 위치를 정리한 것이다.

Figure 5(c) 및 (d)는 표면의 종방향 응력분포를 나타낸 것으로 해석 모델 좌측 단부에서 $10 \mathrm{~mm}, 60 \mathrm{~mm}, 110 \mathrm{~mm}$ 및 $157.5 \mathrm{~mm}$ (해석 모델 중앙) 떨어진 위치에서의 종방향 응력분포이다. 좌측 단부에서 $10 \mathrm{~mm}$ 와 $60 \mathrm{~mm}$ 떨어진 위치에서는 길이방향(종방향)으로 갈수록 유사한 양상의 응력분포를 나타내며, 상부면에서는 각각 $0.54 \mathrm{MPa}$, $3.21 \mathrm{MPa}$ 의 최대 인장응력이 발생하였고 이 응력은 $0.4 \mathrm{~b}$ 위치와 $1.0 \mathrm{~b}$ 위치에서 크기가 $0 \mathrm{MPa}$ 로 수렴하였다. 또, $110 \mathrm{~mm}$ 와 $157.5 \mathrm{~mm}$ 떨어진 위치에서도 비슷한 앙상의 응력분포를 나타냈다. 상부면에 서는 각각 $4.2 \mathrm{MPa}, 4.8 \mathrm{MPa}$ 의 인장응력이 발생하였고, 길이방향으 로 $0.2 b$ 떨어진 위치에서 $6.93 \mathrm{MPa}, 9.22 \mathrm{MPa}$ 의 최대 인장응력을 나타냈으며, $1.0 b$ 위치에서 응력이 $0 \mathrm{MPa}$ 로 수렴하였다. 따라서, 
Table 1. Summary of lateral stress distributions on surface (unreinforced model)

\begin{tabular}{c|c|c|c|c}
\hline \hline \multirow{2}{*}{ lateral stresses } & \multicolumn{4}{|c}{ locations } \\
\cline { 2 - 5 } & $10 \mathrm{~mm}$ & $0.3 b$ & $0.5 b$ & $1.0 b$ \\
\hline Max. tensile stress (MPa) & 6.78 & 6.91 & 3.20 & 0 \\
\hline location of max. stress & center & center & center & - \\
\hline
\end{tabular}

Table 2. Summary of longitudinal stress distributions on surface (un-reinforced model)

\begin{tabular}{c|c|c|c|c}
\hline \hline \multirow{2}{*}{ longitudinal stress } & \multicolumn{4}{|c}{ locations } \\
\cline { 2 - 5 } & $10 \mathrm{~mm}$ & $60 \mathrm{~mm}$ & $110 \mathrm{~mm}$ & $157.5 \mathrm{~mm}$ \\
\hline Max. tensile stress (MPa) & 0.54 & 3.21 & 6.93 & 9.22 \\
\hline locations of max. stress & upper face & upper face & $0.2 b$ & $0.2 b$ \\
\hline
\end{tabular}
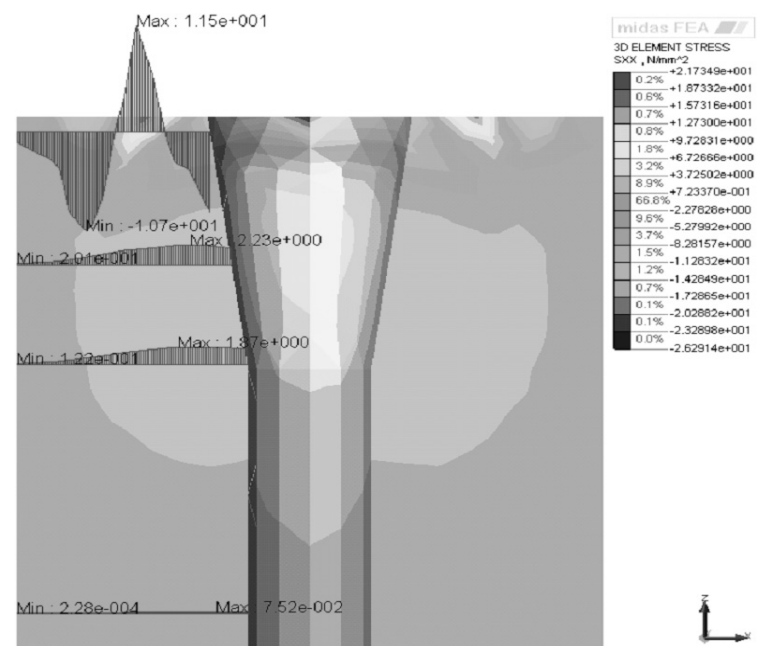

(a) Lateral stresses distributions(inside)

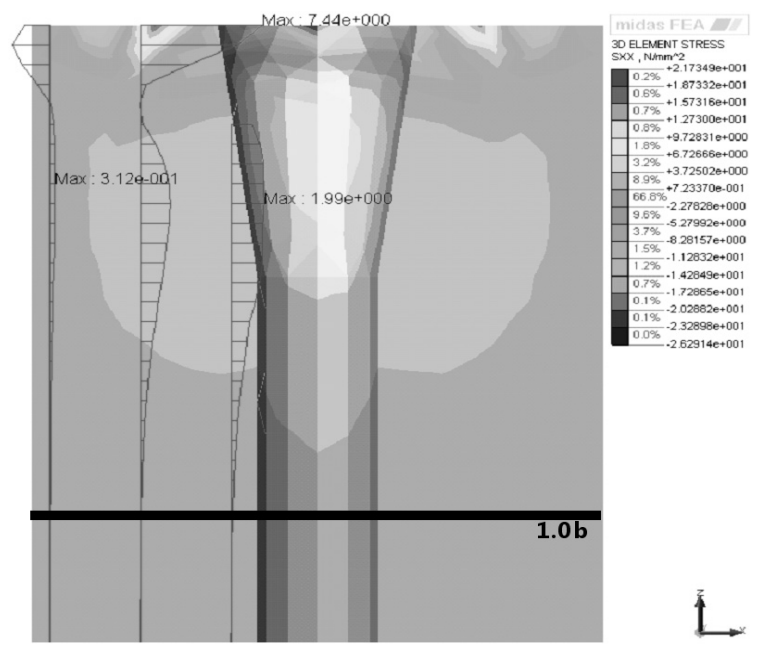

(c) Longitudinal stress distributions(inside)
단면치수와 같은 깊이에서 교란영역을 넘어서는 범위로 $0 \mathrm{MPa}$ 에 수렴하였으며, 이는 보통 콘크리트에 대한 탄성해석 결과와 동일한 응력분포특성을 보이는 것이다(최규천 등, 2010). 즉, 초고강도 콘크리트의 경우에는 인장강도 값이 일반 콘크리트에 비하여 매우 크므로 발생하는 설계하중에 따른 인장응력의 크기가 탄성 범위 내에 있어 탄성해석을 통한 응력분포 특성의 검토가 의미있다고 할 수 있다. Table 2 는 무보강 해석 모델 표면에서 발생한 종방향 응력분포의 최대 인장응력과 발생한 위치를 정리한 것이다.

(2) 내부(횡단면)의 응력분포

표면의 응력분포를 해석한 해석 모델의 모델을 $1 / 2$ 단면으로 자른 후 내부(횡단면)의 응력분포를 확인하였다. 해석 결과는 표면 의 해석과 동일한 위치에서 이루어졌으며 횡방향 응력의 경우

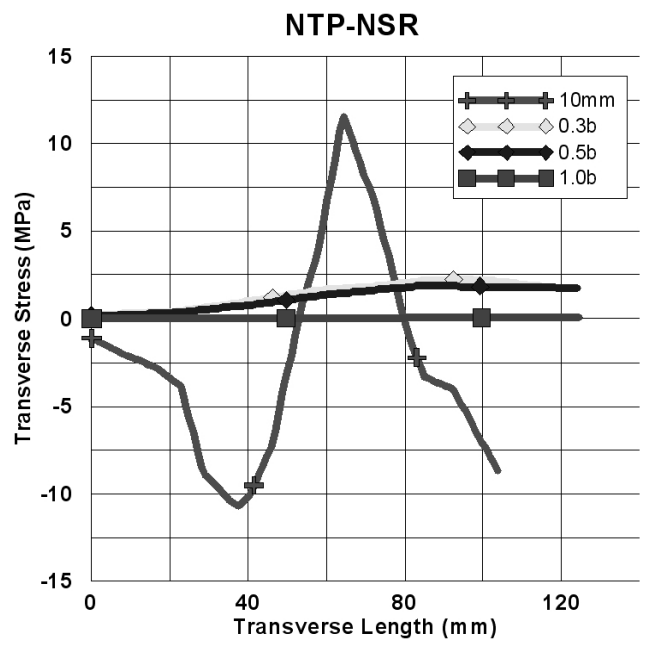

(b) Lateral stress changes(inside)

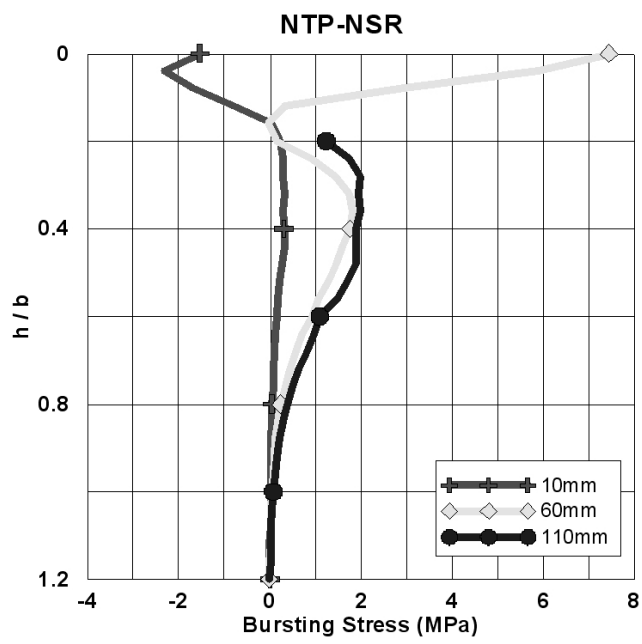

(d) Longitudinal stress changes(inside)

Fig. 6. Stress distributions inside (un-reinforced model) 
좌측 단부에서 강연선이 삽입되는 덕트까지 측정하였고, 종방향 응력의 경우 $157.5 \mathrm{~mm}$ 위치는 덕트 내부의 빈 공간으로 해석에서 제외하였다. Figure 6은 UHPC를 적용하고 정착장치 및 구속철근 배근하지 않은 해석 모델 내부의 횡방향 및 종방향의 응력분포를 나타내고 있다.

Figure 6(a) 및 (b)는 내부의 횡방향 응력분포를 나타낸 것으로, 상부면에서 $10 \mathrm{~mm}$ 떨어진 위치에서는 해석 모델 좌측 단부에서 중앙 으로 갈수록 불규칙한 응력분포를 나타내었다. 단부에서 $1.12 \mathrm{MPa}$ 의 압축응력이 발생하고 최대 압축응력은 단부에서 $37 \mathrm{~mm}$ 떨어진 위치에서 $10.8 \mathrm{MPa}$ 의 압축응력이 발생하였으며 $64 \mathrm{~mm}$ 위치에서 $11.5 \mathrm{MPa}$ 의 최대 인장응력이 발생하였다. 이는 정착판 $(215 \mathrm{~mm})$ 의 영향으로 인해 단부에서 $64 \mathrm{~mm}$ 떨어진 위치에서 높은 인장응력이 발생한 것으로 판단된다. $0.3 b$ 와 $0.5 b$ 위치의 응력분포는 표면의 응력분포와 비슷한 양상을 보이며 좌측 단부에서 $0 \mathrm{MPa}$ 에 가까운 응력 값을 보였으며, $10 \mathrm{~mm}$ 떨어진 위치에 비해 선형적인 분포를 나타냈다. 또한 응력의 크기는 동일하게 해석 모델 중앙으로 갈수록 응력이 증가하고 최대 인장응력 또한 해석 모델 중앙에서 각각 $2.2 \mathrm{MPa}$ 과 $1.9 \mathrm{MPa}$ 의 값을 나타쌨다. $1.0 \mathrm{~b}$ 떨어진 위치에서는 $0 \mathrm{MPa}$ 의 일정한 값을 나타내는데, 이 또한 표면의 응력분포와 동일한 분포를 나타냈다. 따라서, 내부의 횡방향 응력은 $10 \mathrm{~mm}$ 떨어진 위치의 응력을 제외하고 해석 모델 중앙에서 가장 큰 응력 값을 나타냈다. 즉, 하중재하면에서 가까운 위치의 경우 국부적인 응력장 의 교란으로 압축응력 및 인장응력이 교대로 발생하였으나, 하중재 하면으로부터 떨어진 곳에서는 최대 응력의 값이 중앙에서 일어나 는 것을 의미한다. Table 3 은 무보강 해석 모델 내부에서 발생한 횡방향 응력분포의 최대 인장응력과 발생한 위치를 정리한 것이다.

Figure 6(c) 및 (d)는 내부의 종방향 응력분포를 나타낸 것으로, 좌측 단부에서 $10 \mathrm{~mm}$ 떨어진 위치에서는 $0.32 b$ 위치에서 $0.31 \mathrm{MPa}$ 의 최대 인장응력이 발생하였고 $0.9 b$ 위치에서 $0 \mathrm{MPa}$ 로 응력이

Table 3. Summary of lateral stress distributions inside (un-reinforced model)

\begin{tabular}{c|c|c|c|c}
\hline \hline \multirow{2}{*}{ lateral stresses } & \multicolumn{4}{|c}{ Locations } \\
\cline { 2 - 5 } & $10 \mathrm{~mm}$ & $0.3 b$ & $0.5 b$ & $1.0 b$ \\
\hline Max. tensile stress (MPa) & 11.50 & 2.20 & 1.90 & 0 \\
\hline locations of max. stress & $64 \mathrm{~mm}$ & center & center & - \\
\hline
\end{tabular}

Table 4. Summary of longitudinal stress distributions inside (unreinforced model)

\begin{tabular}{c|c|c|c}
\hline \hline \multirow{2}{*}{ Longitudinal stresses } & \multicolumn{3}{|c}{ Locations } \\
\cline { 2 - 4 } & $10 \mathrm{~mm}$ & $60 \mathrm{~mm}$ & $110 \mathrm{~mm}$ \\
\hline Max. tensile stress (MPa) & 0.31 & 7.40 & 2.00 \\
\hline locations of max. stress & $0.32 b$ & Upper face & $0.36 b$ \\
\hline
\end{tabular}

수렴하였다. $60 \mathrm{~mm}$ 떨어진 위치의 경우 하중재하면에서 $7.4 \mathrm{MPa}$ 의 최대 인장응력이 발생하였고 길이방향으로 가면서 불규칙한 응력분 포 양상을 보였으며 $1.12 b$ 위치에서 $0 \mathrm{MPa}$ 로 수렴하였다. $110 \mathrm{~mm}$ 떨어진 위치의 경우 정착장치가 삽입 될 부분을 제외하고 계측한 결과 $0.36 b$ 위치에서 $2 \mathrm{MPa}$ 의 최대 인장응력이 발생하였으며 $1.16 b$ 위치에서 $0 \mathrm{MPa}$ 로 수렴하였다. 따라서, 표면에서의 응력분 포와 같이 응력 계산 위치에 따라 표면부에는 일부 압축응력이 발생하였으나, 최대 인장응력 발생위치는 $0.4 b$ 부근으로 단면 크기 결정 시 해석한 내용과 큰 차이를 보이지 않았으며, 내부에 발생한 횡방향 파열응력의 경우도 단면 치수와 같은 깊이에서는 교란영역 을 넘는 범위로 판단되며 $0 \mathrm{MPa}$ 로 수렴하였다. Table 4 는 무보강 해석 모델 내부에서 발생한 종방향 응력분포의 최대 인장응력과 발생한 위치를 정리한 것이다.

\subsection{2 정착장치 및 구속철근 보강 모델(TP-SR)의 응력분포}

(1) 표면의 응력분포

정착판 및 구속 보강철근의 효과를 무보강 모델과 비교하기 위하여 정착장치 및 구속철근으로 보강 된 해석 모델 표면의 횡방향 및 종방향의 응력해석을 수행하였는데, Figure 7(a) 및 (c)는 유한요 소해석 결과를 도시한 것이며, Figure 7(b) 및 (d)는 그 결과를 그래프 로 정리한 것이다.

Figure 7(a) 및 (b)는 표면의 횡방향 응력분포를 나타낸 것으로 상부면에서 $10 \mathrm{~mm}$ 떨어진 위치에서는 좌측 단부에서는 $0 \mathrm{MPa}$ 에 가까운 응력 값을 나타냈으며 $108 \mathrm{~mm}$ 떨어진 위치에서 $1.48 \mathrm{MPa}$ 의 최대 인장응력이 발생하였다. 발생한 응력은 해석 모델 중앙 $(157.5 \mathrm{~mm})$ 으로 가면서 불규칙한 분포를 보이고 증가한 응력은 다시 $0 \mathrm{MPa}$ 로 수렴하는 양상이 나타났다. $0.3 \mathrm{~b}$ 와 $0.5 \mathrm{~b}$ 위치의 응력은 무보강 해석 모델과 동일한 응력분포를 보이며 해석 모델의 좌측 단부에서 $0 \mathrm{MPa}$ 에 가까운 응력 값을 보이고 $10 \mathrm{~mm}$ 떨어진 위치에 비해 선형적 인 분포를 나타냈고 응력의 크기는 동일하게 해석 모델 중앙으로 갈수록 응력이 증가하고 최대 인장응력 또한 해석 모델 중앙에서 각각 $6.25 \mathrm{MPa}$ 과 $3.68 \mathrm{MPa}$ 의 값을 나타냈다. $1.0 \mathrm{~b}$ 떨어진 위치에서 또한 단부에서는 $0 \mathrm{MPa}$ 정도의 일정한 값을 나타냈으나 해석 모델 중앙으로 갈수록 $0.5 \mathrm{MPa}$ 의 최대 인장응력이 발생하였다. Table 5 는 정착장치 보강 해석 모델 표면에서 발생한 횡방향 응력분포의 최대 인장응력과 발생한 위치를 정리한 것이다.

Figure 7(c) 및 (d) 또한 무보강 해석 모델의 표면에서 응력분포 와 같은 위치에서 응력분포를 확인하였는데, 좌측 단부에서 $10 \mathrm{~mm}$ 떨어진 위치에서는 길이방향(종방향)으로 갈수록 감소하는 일정한 양상의 응력분포를 나타내며, $0.4 b$ 위치에서 $0.14 \mathrm{MPa}$ 의 최대 인장 응력을 보였다. $60 \mathrm{~mm}$ 떨어진 위치에서는 상부면에서 $0.67 \mathrm{MPa}$ 의 인장응력을 보이고 $0.3 b$ 위치에서 $1.77 \mathrm{MPa}$ 의 최대 인장응력이 

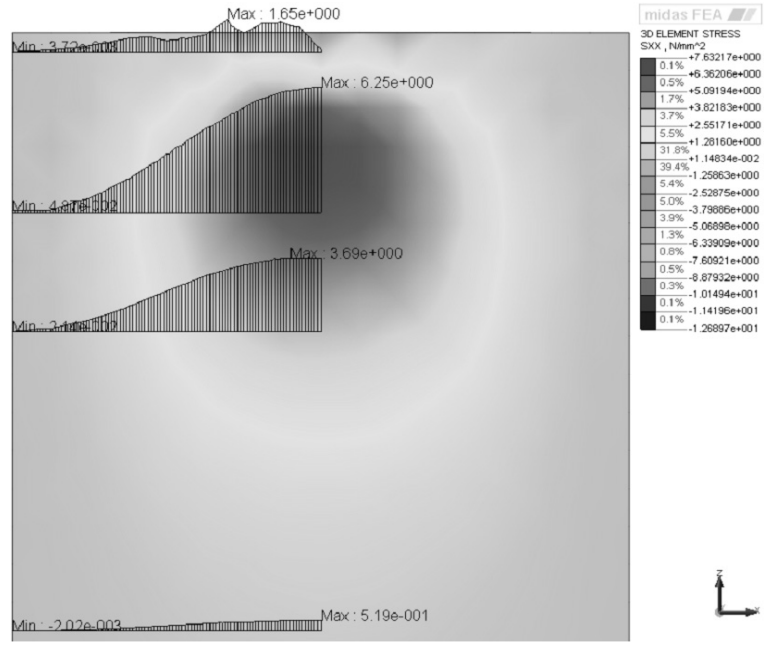

(a) Lateral stress distributions(surface)

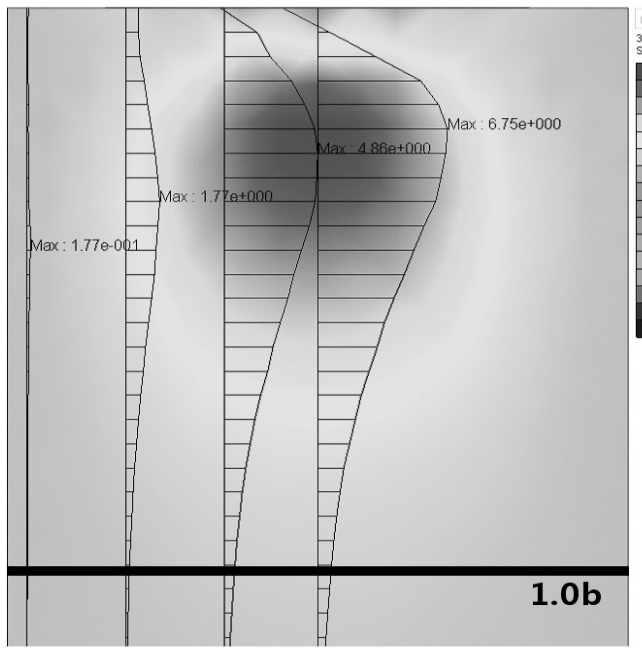

(c) Longitudinal stress distributions(surface)

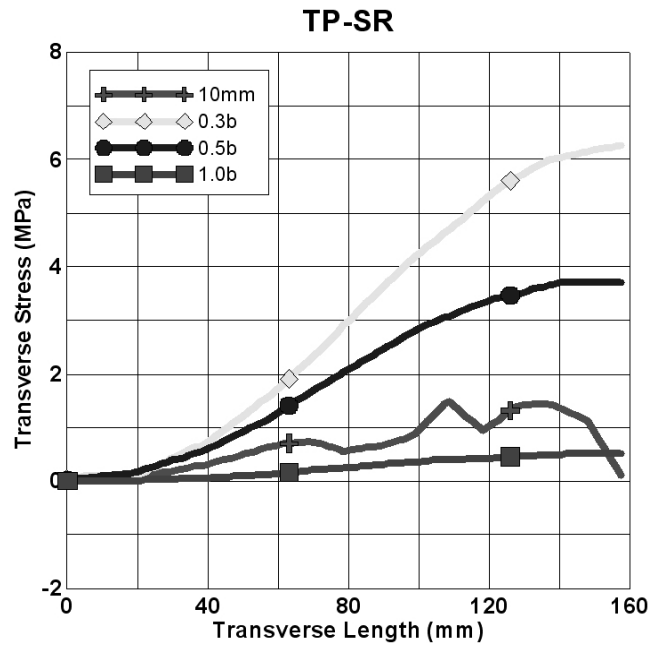

(b) Lateral Stress Changes(surface)

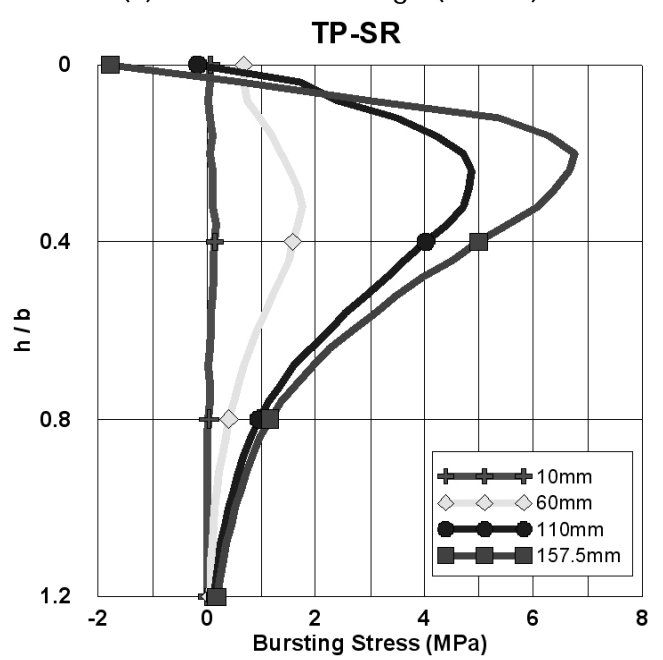

(d) Longitudinal stress changes(surface)

Fig. 7. Stress distributions on surface(reinforced model)

발생하였고 $1.0 \mathrm{~b}$ 떨어진 위치에서 $0 \mathrm{MPa}$ 로 수렴하는 응력값을 나타냈다. $110 \mathrm{~mm}$ 와 $157.5 \mathrm{~mm}$ 떨어진 위치에서는 무보강 해석 모델과는 달리 상부면에서 각각 $0.2 \mathrm{MPa}$ 과 $1.78 \mathrm{MPa}$ 의 압축응력이 나타났으며 이 응력은 길이방향으로 내려갈수록 인장응력으로 변 화하였고, 각각 $0.2 b$ 위치에서 $4.86 \mathrm{MPa}, 6.75 \mathrm{MPa}$ 의 최대 인장응 력이 발생하였으며 이 응력은 $1.0 b$ 위치에서 응력이 $0 \mathrm{MPa}$ 에 가까 운 값으로 수렴하였다. 따라서, 무보강 해석 모델과 비슷한 응력분포 를 보이며 단면치수와 같은 깊이에서 교란영역을 넘어서는 범위로 $0 \mathrm{MPa}$ 에 수렴하였다. 이는 일반적인 보통 콘크리트의 PS 정착부에 서 보이는 응력분포와 동일한 응력분포특성을 보이는 것으로 초고 강도 콘크리트 정착부의 경우도 특별한 차이를 보이지 않았다(김지 상 등, 2011). Table 6은 정착장치 보강 해석 모델 표면에서 발생한 횡방향 응력분포의 최대 인장응력과 발생한 위치를 정리한 것이다.
Table 5. Summary of lateral stress distributions on surface (reinforced model)

\begin{tabular}{c|c|c|c|c}
\hline \multirow{2}{*}{ Lateral stresses } & \multicolumn{4}{|c}{ Locations } \\
\cline { 2 - 5 } & $10 \mathrm{~mm}$ & $0.3 b$ & $0.5 b$ & $1.0 b$ \\
\hline Max. tensile stress (MPa) & 1.48 & 6.25 & 3.68 & 0.50 \\
\hline locations of max. stress & $\begin{array}{c}108 \mathrm{~mm} \text { from the } \\
\text { surface }\end{array}$ & center & center & center \\
\hline
\end{tabular}

Table 6. Summary of longitudinal stress distributions on surface (reinforced model)

\begin{tabular}{c|c|c|c|c}
\hline \hline \multirow{2}{*}{ Longitudinal stresses } & \multicolumn{4}{|c}{ Locations } \\
\cline { 2 - 5 } & $10 \mathrm{~mm}$ & $60 \mathrm{~mm}$ & $110 \mathrm{~mm}$ & $157.5 \mathrm{~mm}$ \\
\hline Max. tensile stress $(\mathrm{MPa})$ & 0.14 & 1.77 & 4.86 & 6.75 \\
\hline locations of max. stress & $0.4 b$ & $0.3 b$ & $0.2 b$ & $0.2 b$ \\
\hline
\end{tabular}



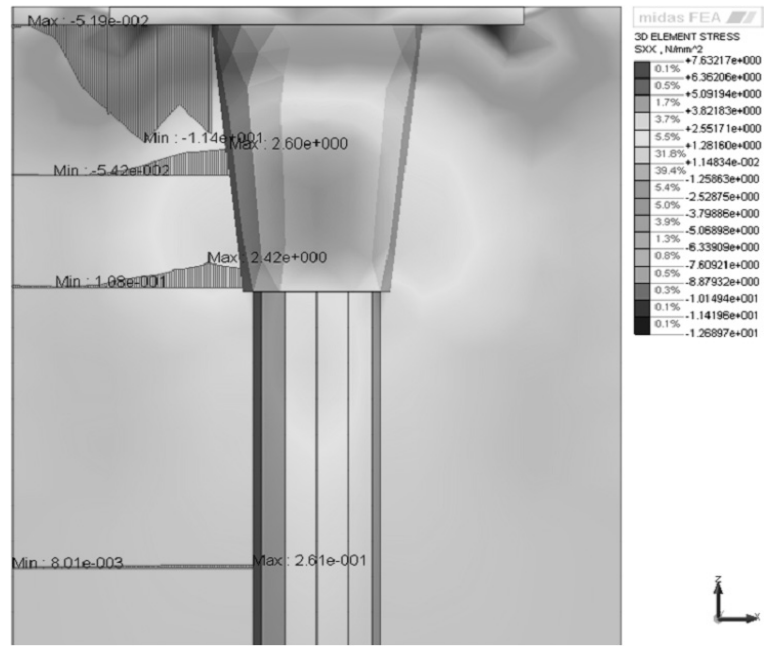

(a) Lateral stress distributions(inside)
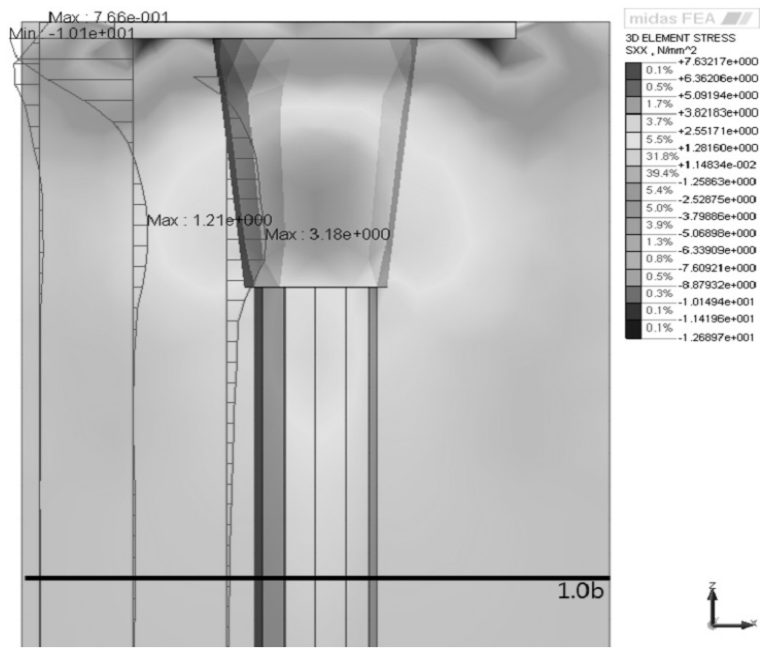

(c) Longitudinal stress distributions(inside)

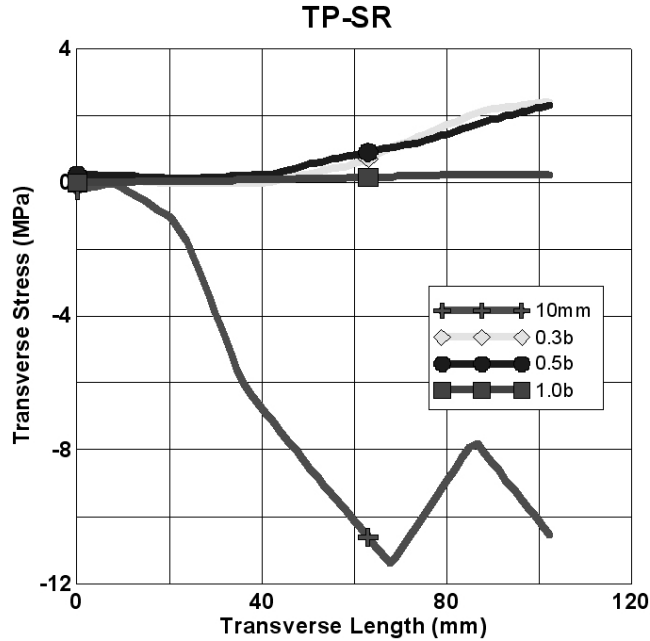

(b) Lateral stress changes (inside)

TP-SR

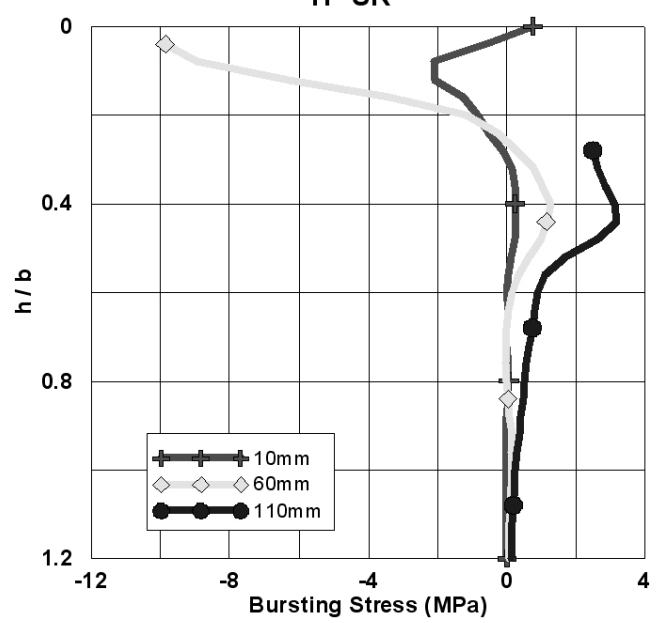

(d) Longitudinal stress changes(inside)

Fig. 8. Stress distributions inside(reinforced model)

(2) 내부(횡단면)의 응력분포

정착장치 및 구속철근 보강 해석 모델 내부의 응력분포는 정착장 치가 해석 모델에 삽입되는 점을 고려하여 $60 \mathrm{~mm}$ 와 $110 \mathrm{~mm}$ 의 위치는 무보강 해석 모델에 비하여 $10 \sim 80 \mathrm{~mm}$ 정도 떨어진 부분에 서 응력을 계산하였다. Figure 8(a) 및 (b)는 해석 모델 내부의 횡방향 응력분포를 나타낸 것으로, 상부면에서 $10 \mathrm{~mm}$ 떨어진 위치 에서는 해석 모델 좌측 단부에서 중앙으로 갈수록 불규칙한 응력분 포를 나타내며 정착판이 삽입되어 해석 모델과 맞닿는 부분에서는 $11.23 \mathrm{MPa}$ 의 최대 압축응력이 발생하고 응력은 정착장치에 가까워 지면서도 압축응력분포를 유지하였다. $0.3 b$ 떨어진 위치에서는 해석 모델 좌측단부에서 $45 \mathrm{~mm}$ 떨어진 위치까지는 $0 \mathrm{MPa}$ 로 일정한 값을 나타냈으나 이후 인장응력이 발생하면서 정착장치와 맞닿는 부분에서 $2.41 \mathrm{MPa}$ 의 최대 인장응력을 보였으며, $0.5 b$ 떨어진 위치
에서도 $0.3 \mathrm{~b}$ 위치의 응력분포와 비슷한 응력분포를 나타내며 정착 장치와 맞닿는 부분에서 $2.27 \mathrm{MPa}$ 의 최대 인장응력 값을 나타내었 다. $1.0 \mathrm{~b}$ 떨어진 위치에서는 $0 \mathrm{MPa}$ 로 일정한 값을 보이며 해석 모델 중앙에서 $0.2 \mathrm{MPa}$ 의 값을 나타냈다. Table 7 은 정착장치 보강 해석 모델 내부에서 발생한 횡방향 응력분포의 최대 인장응력 과 발생한 위치를 정리한 것이다.

Figure 8(c) 및 (d)는 표면 해석과 동일한 위치에서의 파열응력을 계산한 것을 도시한 것으로 단부에서 $10 \mathrm{~mm}$ 떨어진 위치에서의 인장응력은 상부면에서 $0.76 \mathrm{MPa}$ 의 인장응력을 나타냈다. 이후 길이방향으로 $0.08 b$ 위치에서 $2.09 \mathrm{MPa}$ 의 최대 압축응력이 발생하 였고, $0.3 b$ 위치에서 다시 인장응력분포를 나타넸으며, $0.42 b$ 위치 에서 $0.26 \mathrm{MPa}$ 의 최대 인장응력이 발생하였다. 이후 응력은 $0.8 b$ 위치에서 $0 \mathrm{MPa}$ 로 수렴하였다. $60 \mathrm{~mm}$ 떨어진 위치에서의 인장응 
Table 7. Summary of lateral stress distributions inside (reinforced model)

\begin{tabular}{c|c|c|c|c}
\hline \hline \multirow{2}{*}{ Lateral stresses } & \multicolumn{4}{|c}{ Locations } \\
\cline { 2 - 5 } & $10 \mathrm{~mm}$ & $0.3 b$ & $0.5 b$ & $1.0 b$ \\
\hline Max. tensile stress (MPa) & -11.23 & 2.41 & 2.27 & 0.20 \\
\hline locations of max. stress & $70 \mathrm{~mm}$ from surface & center & center & center \\
\hline
\end{tabular}

Table 8. Summary of longitudinal stress distributions inside (reinforced model)

\begin{tabular}{c|c|c|c}
\hline \hline \multirow{2}{*}{ Longitudinal stresses } & \multicolumn{3}{|c}{ Locations } \\
\cline { 2 - 4 } & $10 \mathrm{~mm}$ & $60 \mathrm{~mm}$ & $110 \mathrm{~mm}$ \\
\hline Max. tensile stress $(\mathrm{MPa})$ & 0.26 & 1.14 & 3.20 \\
\hline locations of max. stress & $0.42 b$ & $0.44 b$ & $0.44 b$ \\
\hline
\end{tabular}

력은 상부면에서 정착장치의 영향으로 $9.8 \mathrm{MPa}$ 의 최대 압축응력이 발생하였고 발생한 압축응력은 $0.3 b$ 위치에서 인장응력을 나타냈 다. 또한, $0.44 b$ 위치에서 $1.14 \mathrm{MPa}$ 의 최대 인장응력이 발생하였으 며, 인장응력은 $0.8 \mathrm{MPa}$ 에서 $0 \mathrm{MPa}$ 로 수렴하였다. $110 \mathrm{~mm}$ 떨어진 위치의 인장응력은 정착장치의 영향으로 $0.28 b$ 떨어진 위치에서부 터 응력을 계산하였는데, 그 값은 $2.49 \mathrm{MPa}$ 로 나타났다. 발생한 인장응력은 $0.44 b$ 위치에서 $3.2 \mathrm{MPa}$ 의 최대 인장응력을 나타냈고, $1.2 b$ 위치에서 $0 \mathrm{MPa}$ 로 수렴하는 양상을 나타냈다. 표면에서의 인장응력 분포를 해석한 결과와 같이 응력 계산 위치에 따라 표면부 에는 일부 압축응력이 발생하였으나, 최대 인장응력의 발생위치는 $0.4 b$ 부근으로 단면 크기 결정 시 해석한 내용과 큰 차이를 보이지 않았으며, 내부에 발생한 횡방향 인장응력의 경우정착장치의 영향 으로 인해 단면치수보다 다소 깊은 위치에서 $0 \mathrm{MPa}$ 로 수렴하였다. Table 8 은 정착장치 보강 해석 모델 표면에서 발생한 횡방향 응력분 포의 최대 인장응력과 발생한 위치를 정리한 것이다.

\subsection{3 해석 결과 비교}

무보강 해석 모델과 정착장치 및 구속철근 보강 모델의 횡방향 응력분포와 종방향 응력분포를 비교한 것이 Figure 9이다. 계측 위치에 따라 정착장치의 영향으로 인한 내부의 빈 공간은 해석에서 제외하여 비교하였으며, 횡방향 응력 분포는 경우 가장 큰 인장응력 이 발생하는 상부면으로부터 $0.3 b$ 떨어진 위치에서 그 값을 비교하 였고, 종방향 응력분포의 경우 좌측 단부에서 $110 \mathrm{~mm}$ 떨어진 위치 에서의 응력을 비교하였다. 횡방향 응력의 표면 응력분포는 무보강 해석 모델이 보강 실험체에서보다 $0.7 \mathrm{MPa}$ 정도 큰 인장응력을 나타냈으며, 내부의 응력은 거의 비슷한 수준의 최대인장응력 값을 나타냈다. 표면과 내부의 응력크기는 $4 \mathrm{MPa}$ 정도의 차이를 나타낸 다. 종방향 응력 분포의 경우 무보강 해석 모델의 표면에서는 인장응 력만 분포한데 비해 정착장치 및 구속철근 보강 해석 모델의 경우
NTP-NSR Vs. TP-SR

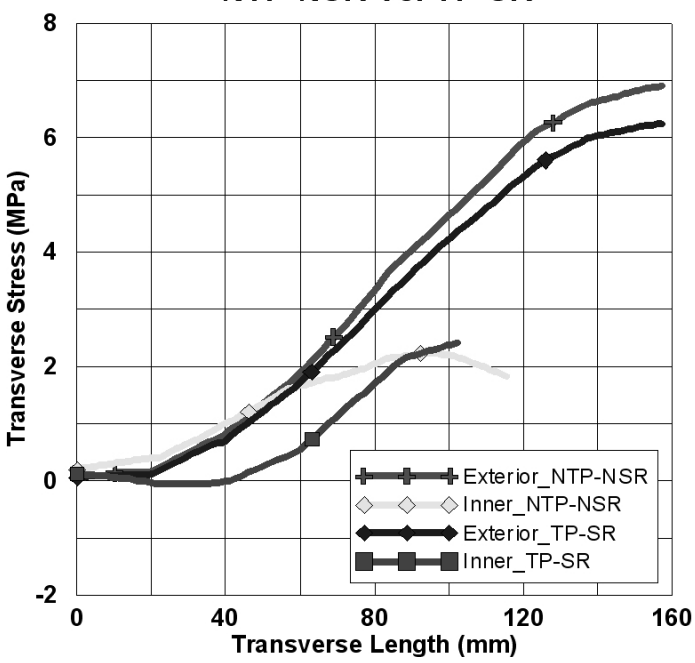

(a) Lateral stresses

NTP-NSR Vs. TP-SR

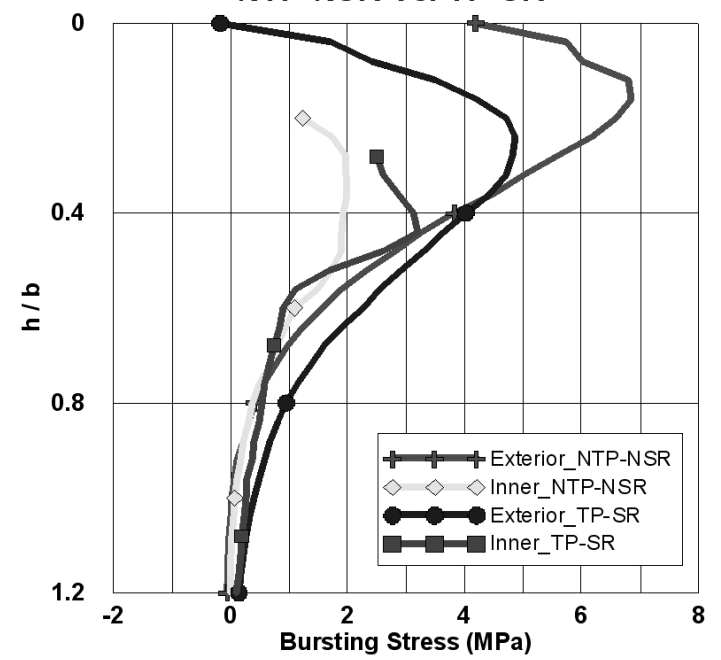

(b) Longitudinal stresses

Fig. 9. Comparison of stress distributions between un-reinforced and reinforced models

상부면에서 압축응력이 분포하다 다시 인장응력이 분포하는 양상 을 보이며, 보통 콘크리트의 응력분포(최규천 등, 2010)와 비슷한 양상을 보였다. 표면과 내부의 인장응력을 비교하여 보면 무보강실 험체 및 보강실험체 모두에서 표면에서의 응력이 내부에서 계산된 응력값의 2 배 이상 큰 값을 나타냈다.

\subsection{4 파열력 크기 검토}

현재 초고강도 콘크리트를 적용한 PS 정착부의 설계에 적용할 수 있는 별도의 설계기준이 없어 도로교설계기준에서 제시한 유한 요소 해석법에 의한 간략식과 이 논문의 해석 결과를 비교하였다. 도로교설계기준에서 제시한 근사해법에 의한 파열력은 식 (1)로부 


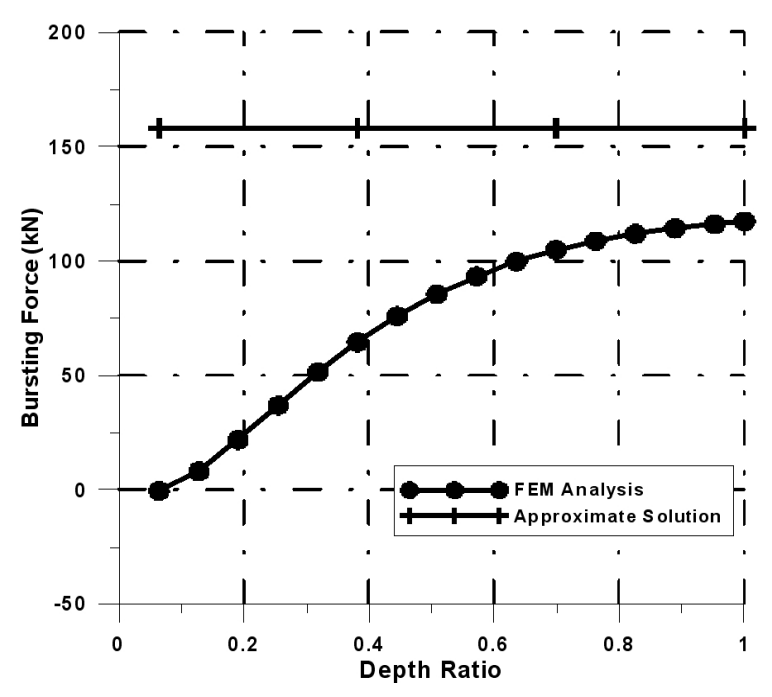

Fig. 10. Bursting forces from FEM and approximate design equation

터 산정되는데, 이 논문에서 대상으로 한 해석 모델에 발생하는 파열력은 $158 \mathrm{kN}$ 이 된다.

$$
T_{\text {burst }}=0.25 \sum P_{u}(1-a / h)+0.5 P_{u} \sin \alpha
$$

$T_{\text {burst }}$ : 파열력

$P_{u} \quad$ : 각 정착구에 작용하는 계수긴장력, 계수 축하중 $(\mathrm{N})$

$a$ : 정착판의 폭

$h \quad$ : 고려하는 방향에서의 단면의 횡방향 규격 $(\mathrm{mm})$

$\alpha \quad$ : 부재 중심선에 대한 긴장력의 합력의 경사각(degree)

Figure 10 은 유한요소해석을 통해 얻은 결과를 바탕으로 파열력 을 계산한 것이며, 상부면에서 $1.0 b$ ( $b=$ 단면 폭)위치 이후 모든 파열력이 일정한 값으로 수렴하는 앙상을 보이기 때문에 $1.0 b$ 위치까지의 누적 파열력 $(117.5 \mathrm{kN})$ 을 계산하였고, 이 값은 근사해 법을 통한 파열력 $(158 \mathrm{kN})$ 에 비해 약 $3 / 4$ 배 정도의 작은 값을 나타낸다. 이는 UHPC를 이용한 프리스트레스트 콘크리트 정착구 에 있어서 보강장치의 유무가 파열응력의 크기에 절대적인 영향을 주지 못하고, 유한요소해석 결과에 따르면 보강철근을 배치하는 경우 매우 보수적인 결과가 되므로, 별도의 구속철근 없이도 파열력 에 충분히 저항할 수 있는 하중재하능력 기준을 만족하는 것으로 사료된다.

\section{4. 결론}

이 연구에서는 국내에서 개발한 UHPC를 프리스트레스트 콘크 리트 부재에 적용할 경우 정착부의 역학적 거동을 유한요소해석을
수행하여 파열응력 및 변형률 분포를 확인하였으며, 향후 실험적 연구에 반영할 기초자료로 활용될 것이다. 그 결론을 정리하면 다음과 같다.

(1) 최대 파열응력의 크기는 $11.5 \mathrm{MPa}$ 로 나타났는데, 국내에서 개발한 $\mathrm{UHPC}$ 의 경우 충분한 안전율을 고려하여도 $10 \mathrm{MPa}$ 이상의 인장강도를 갖고 있어 별도의 보강철근 없이도 유럽기 준인 ETAG-013에서 제시한 수직균열에 의한 파괴없이 저항 할 수 있는 하중재하능력의 기준을 만족하는 것을 확인하였다.

(2) 최대 파열응력 및 최대 변형률의 위치는 $0.2 b$ 부근이고, 단면치 수와 같은 깊이 즉, 교란영역을 넘어서는 범위에서 일정한 값으로 수렴하는 것으로 나타났다.

(3) 도로교설계기준에서 제시된 근사해법과 유한요소해석을 통해 계산된 파열력을 비교한 결과 각 각 $158 \mathrm{kN}$ 과 $117.5 \mathrm{kN}$ 의 값을 나타넸으며, 이는 구속철근 보강 없이도 파열력에 저항할 수 있는 하중재하능력을 만족하는 것으로 확인하였다. 현재의 설계기준에 따라 보강철근을 배치하는 경우 과도하게 안전측의 설계가 될 것으로 사료된다.

\section{감사의 글}

본 연구는 한국건설기술연구원 주요사업(기존 PSC 교량의 텐던 상태평가 기술 개발)의 연구비 지원에 의해 수행되었습니다.

\section{References}

AFGC (French Association of Civil engineers)/SETRA. (2002). Ultra high performance fibre-reinforced concretes, Interim RecomMendations.

Behloul, M., Lee, K. C. and Etienne. D. (2004). "Seonyu ductal ${ }^{\circledR}$ footbridge, in concrete structures: the challenge of creativity." Proc. fib Symp., AFGC, Avignon, Paris, pp. 26-28.

Boulay, C., Toulemonde, F., Clement, J. L., Verok, K. and Fakhri, P. (2004). "Safety of HSC structures under concentrated loading: Experimental approach." Magazine of Concrete Research 56(9), pp. 523-535.

Choi, K. C., Park, Y. H. and Paik, I. Y. (2010). "Evaluation of bursting behavior in anchorage zone of PSC I girders." Journal of KSCE, KSCE, Vol. 30, No. 3A, pp. 329-336 (in Korean).

DAfStb (German Committee for Reinforced Concrete) (2008). Interim report: Ultra High Performance Concrete (in German).

EOTA (2002). ETAG-013 : Guideline for european technical approval of post-tensioning kits for prestressing of structures.

FHWA (2006). Structural behavior of ultra-high performance concrete prestressed I-girders, FHWA-HRT-06-115, VA.

Hajar, Z., Simon, A., Thibaux, T. and Wyniecki, P. (2004). "Construction performance fibre reinforced concrete thin- shell structure over 
the Millau Viaduct toll gate, In Concrete Structures: the Challenge of Creativity." Proc. fib Symp., AFGC, Avignon, Paris, pp. 26-28.

Japan Society of Civil Engineers (2004). Recommendations for design and construction of ultra high strength fiber reinforced concrete structures-draft (in Japanese).

Korea Concrete Institute (2009). Construction specification and commentary of concrete structures (in Korean).

Korea Institute of Construction Technology (2010). Interim design recommendations for ultra high performance concrete and commentary (in Korean).

Korea Institute of Construction Technology (2011). Design specific technology for ultra high performance concrete, KICT 2010-107 (in Korean).

Kim, J. S., Kwark, J. W., Joh, C. b. and Choi, Y. S. (2011). Development of design guide of PS anchorage using ultra high performance concrete, Seokyeong University (in Korean). MIDAS IT (2006). Getting started \& tutorials (in Korean). Ministry of Land, Transport and Marine Affairs (2010). Korea bridge design code (in Korean).

Oh, B. H., Lim, D. H. and Yoo, S. W. (1994). "Mechanical behavior of anchorage zones in prestressed concrete members with single and closely-spaced anchorages." Journal of KSCE, KSCE, Vol. 14, No. 6, pp. 1329-1339 (in Korean).

Research Institute of Industrial Science \& Technology (2010). Performance test of PT anchorage system (in Korean).

Toutlemonde, F., Renaud, J.-C., Lauvin, L., Behloul, M., Simon, A. and Vildare, S. (2007). "Testing and analysing innovative design of UHPFRC anchor blocks for post-tensioning tendons." 6th International Conference on Fracture Mechanics of Concrete and Concrete Structures (FRAMCOS-6), Catania, Italy, pp. 17-22. 